\title{
STRATEGI PENGEMBANGAN KOMPETENSI GURU SEKOLAH DASAR
}

\author{
Fredy $^{1 *}$, Wa Ode Siti Hamsinah Day ${ }^{2}$ \\ ${ }^{1}$ Universitas Musamus, Merauke, Indonesia \\ ${ }^{2}$ Universitas Halu Oleo, Kendari, Indonesia \\ *Corresponding Author: $\otimes$ fredy_pgsd@unmus.ac.id
}

\begin{tabular}{l} 
Info Artikel \\
\hline Sejarah Artikel: \\
Diterima: $03 / 11 / 2021$ \\
Direvisi : 07/11/2021 \\
Disetujui: $11 / 11 / 2021$ \\
\hline Keywords: \\
Strategy, Competencies, \\
Teacher, Elementary \\
School
\end{tabular}

Kata Kunci:

Strategi, Kompetensi, Guru, Sekolah Dasar
Abstract. The mandate of the law provides instructions teachers have four competencies, including pedagogic, personal, social, and professional. In its implementation, there are still many obstacles by teachers. Lack of skills in applying curriculum 2013, understanding the characteristics of students, knowledge of learning materials, the use of various and innovative learning models and methods, and the use of ICT in learning are obstacles by teachers. This study aims to the strategy of teacher competency development. A qualitative and descriptive approach became the method of this research, using the subject of an elementary school teacher in Bombana district. Data obtained from questionnaires and interviews were analyzed using the IFAS matrix analysis (internal factors analysis summary), EFAS (external factors analysis summary), and SWOT (strengths, weaknesses, opportunities, and threats). The results research an overview of the strategies implemented using the turnaround strategy, taking advantage of existing opportunities to overcome the weaknesses of the teachers for social, professional, and pedagogic competencies. The strategy for personal competence with an aggressive strategy is to use the strengths possessed by the teachers in order to take advantage of the opportunities that exist optimally.

Abstrak. Amanat undang-undang menggariskan bahwa empat kompetensi yang harus dikuasai guru meliputi kompetensi kompetensi kepribadian, pedagogik, kompetensi sosial dan kompetensi professional. Namun dalam pelaksanaanya masih banyak kendala yang dihadapi oleh guru. Kurangnya keterampilan dalam menerapkan kuriulum 2013, pemahaman karakteristik peserta didik, penguasaan terhadap materi pembelajaran, pemanfaatan berbagai metode dan teknik pembelajaran yang beragam dan inovatif serta pemanfaatan ICT dalam pembelajarannya menjadi beberapa kendala yang dihadapi guru. Penelitian ini bertujuan adalah untuk menentukan strategi pengembangan kompetensi guru. Pendekatan kualitatif dan bersifat deskriptif menjadi metode penelitian ini. Dengan menggunakan subjek adalah guru SD di kabupaten Bombana. Data yang diperoleh dari pengisian angket dan wawancara oleh responden dianalisis menggunakan pendekatan matriks IFAS (internal factors analisis strategy), analisis matrik EFAS (external factors analisis strategy) dan analisis SWOT (strengths, weaknesses, opportunities, and threats) serta dilanjutkan ke model grand strategy. Hasil penelitian memberikan gambaran strategi yang diterapkan menggunakan strategi turnarround, yaitu pengembangan kompetensi sosial, profesional dan pedagogik melalui optimalisasi peluang/potensi yang ada untuk mengatasi kekurangan/kelemahan dari guru. Pengembangan kompetensi kepribadian ditempuh dengan strategi agresif yaitu menggunakan kekuatan/keunggulan yang dimiliki oleh guru untuk dapat memaksimalkan peluang yang dimiliki.

How to Cite: Fredy, F., \& Hamsinah Day, W. O. S. (2022). STRATEGI PENGEMBANGAN KOMPETENSI GURU SEKOLAH DASAR. Prima Magistra: Jurnal Ilmiah Kependidikan, 3(1), 30-40. https://doi.org/10.37478/jpm.v3i1.1312

Alamat korespondensi:

J1. Kamizaum Mopah Lama, Merauke

@fredy_pgsd@unmus.ac.id
Penerbit:

Program Studi PGSD Universitas Flores.

(9) primagistrauniflor@gmail.com 


\section{PENDAHULUAN}

Keberadaan pendidikan dalam proses pembangunan memiliki posisi sentral karena luarannya adalah peningkatan mutu SDM (sumber daya manusia) yang merupakan bagian dari perkembangan suatu bangsa. Output dari kualitas pendidikan adalah sejauh mana SDM mampu memenuhi kebutuhannya (Ngurah \& Laksana, 2018). Sebagaimana yang tersurat dalam tujuan pendidikan nasional sebagaimana yang termuat dalam Undang-Undang Nomor 20 Tahun 2003 tentang Sistem Pendidikan Nasional, yakni membangun manusia Indonesia seutuhnya dan mencerdaskan kehidupan berbangsa, yaitu manusia Indonesia meyakini dan mengimani Tuhan Yang Maha Esa dan memiliki kepribadian mencerminkan budaya luhur bangsa, menguasai pengetahuan dan terampil, sehat fisik dan mental, berkarakter baik dan tanggung jawab demi kehidupan berbangsa dan bernegara.

Pendidikan yang berkualitas menempatkan SDM sebagai keutamaan dari output suatu program pendidikan (Fredy et al., 2019). Penyelenggaraan pendidikan yang berkualitas dipengaruhi oleh banyak hal yang tergabung dalam sistem pendidikan itu sendiri, salah satunya adalah dari faktor guru. Peranan guru dalam perwujudan pendidikan berkualitas menjadi penting dikarenakan guru bersama peserta didik merupakan aktor utama dalam sebuah proses pembelajaran sebagai ujung tombak penyelenggaraan sebuah pendidikan. Oleh karena itu pengembangan dan peningkatan SDM membutuhkan sinergitas dan berkesinambungan sehingga dapat menghasilkan perubahan yang optimal (Nurhaidah \& Musa, 2015).

Dalam proses pembelajaran tersebut, guru setidaknya menjalankan tiga peran, yakni 1) merencanakan, guru menyiapkan segala sesuatu yang dibutuhkan dalam proses pembelajaran, 2) melaksanakan, guru menfasilitasi hak peserta didik dengan menghadirkan suasana yang kondusif, membimbing, dan mengarahkan kegiatan belajar, 3) evaluator, guru mengumpulkan, memeriksa, menganalisis, memberi nilai dan mempertimbangkan tingkat keberhasilan proses pembelajaran (Sabaniah et al., 2021).
Hal ini diperkuat oleh pendapat Kartowagiran (2011) bahwa guru profesional memiliki tanggung jawab dalam proses pembelajaran yaitu mendidik, mendampingi, melatih, mengarahkan, dan melaksanakan penilaian peserta didik.

Pengajar dalam hal ini guru dan peserta didik adalah unsur penting dalam pendidikan. Guru memegang posisi sentral dalam pembangunan manusia sehingga tercipta SDM yang berguna untuk pembangunan bangsa. Hal ini dapat dicapai jika guru profesional dan berkualitas dalam menjalakan tugasnya baik sebagai pengajar maupun sebagai pendidik (Jatirahayu, 2013). Jika guru tidak memiliki keprofesionalan dalam menjalankan tugas maka akan sulit bagi peserta didik untuk berkembang dengan baik. Guru harus mampu menebar kebaikan pada peserta didik sehingga melahirkan karakter yang tangguh (Nurhaidah \& Musa, 2015). Faktor utama yang harus dipunyai oleh seorang pengajar ialah kompetensi. Apalagi di abad 21 ini guru dituntut lebih adaptif dan menguasai teknologi guna memenuhi kebutuhan peserta didik dimasa depan (Sofiarini \& Elya Rosalina, 2021).

Mengingat pentingnya tugas-tugas yang harus dilaksanakan tersebut, menjadi seorang guru bukanlah profesi yang secara mudah dapat dijalankan oleh setiap orang. Dibutuhkan persyaratan-persyaratan serta kemampuan-kemampuan yang menjadi syarat mutlak seseorang sehingga dianggap layak menjadi seorang guru. Kemampuankemampuan ini dikenal dengan istilah kompetensi, yang wajib dimiliki oleh seseorang untuk dapat menjadi seorang guru.

Kompetensi dapat diartikan sebagai suatu kemampuan untuk melaksanakan atau melakukan suatu pekerjaan atau tugas yang dilandasi atas keterampilan dan pengetahuan serta didukung oleh etos kerja yang relevan dengan pekerjaan tersebut. Kompetensi yang harus dimiliki oleh guru di Indonesia telah diatur di dalam Peraturan Menteri Pendidikan Nasional Nomor 16 Tahun 2007 Tentang Standar Kualifikasi Akademik dan Kompetensi Guru yang menggariskan bahwa guru di Negara Indonesia setidaknya memiliki empat kompetensi dasar yakni kompetensi 
pedagogik, kompetensi pribadi, kompetensi sosial serta kompetensi professional.

Menurut Undang-Undang Nomor 14 Tahun 2005 Tentang Guru dan Dosen, kompetensi adalah seperangkat pengetahuan, keterampilan, dan sikap yang harus dikuasai dan diamalkan oleh guru atau dosen dalam melaksanakan tugas keprofesionalan. Kompetensi juga dapat diartikan sebagai kecakapan seorang guru dalam melaksanakan tugasnya dengan benar, jujur dan bertanggung jawab (Baharudin, 2017). Pernyataan ini dapat diartikan bahwa kompetensi merupakan perpaduan antara pengetahuan, kemampuan, dan penerapan dalam melaksanakan tugas di lapangan kerja secara bertanggung jawab.

Pengembangan kompetensi guru merupakan hal yang mendesak dikarenakan statusnya sebagai pelaku utama proses pembelajaran di sekolah. Pada umumnya guru SD telah menguasai berbagai teori pembelajaran, prinsip pembelajaran tetapi jarang menerapkan strategi, model dan teknik yang kreatif dan menyenangkan dan kurang menerapkan prinsip penilaian yang menyeluruh (Suhandani \& Julia, 2014). Jika guru telah mempunyai kompetensi yang baik akan melaksanakan tugas dengan penuh semangat dan menyenangkan serta penuh makna, peserta didik akan mendapatkan hal baru setiap kali masuk untuk belajar (Naria et al., 2020). Pada akhirnya akan melahirkan peserta didik yag rajin belajar karena mereka mencintai proses pembelajaran dan memahami arti penting belajar bagi masa depan (Musfah, 2011).

Berdasarkan hasil uji kompetensi guru (UKG) untuk guru SD tahun 2019, Provinsi Sulawesi tenggara tergolong rendah dengan nilai rata-rata sebesar 48,58 sehingga seluruh wilayah kabupaten/ kota yang berada di wilayah Provinsi Sulawesi Tenggara perlu melakukan berbagai upaya untuk meningkatkan kompetensi gurunya masingmasing. Salah satunya adalah Kabupaten Bombana yang ada di wilayah Provinsi Sulawesi Tenggara memiliki nilai UKG masih dibawah nilai UKG provinsi yaitu sebesar 48,19. Strategi pengembangan kompetensi guru perlu dilakukan setelah dilakukan kajian ilmiah, sehingga setiap kebijakan yang diambil dapat tepat sasaran.

Berdasarkan uraian latar belakang permasalahan tersebut, maka peneliti berinisiatif melakukan kegiatan penelitian yang bekerjasama dengan Pemerintah daerah kabupaten Bombana untuk melahirkan suatu model pengembangan peningkatan komptensi guru sekolah dasar.

\section{METODE PENELITIAN}

Desain yang digunakan adalah desain penelitian kualitatif bersifat deskriptif, yaitu memungkinkan untuk mengungkap realita yang mendeskripsikan situasi secara komprehensif dengan konteks yang sebenarnya mengenai kompetensi guru sekolah dasar, meliputi kompetensi kepribadian, sosial, profesional dan pedagogik sebagaimana yang diamanatkan dalam Peraturan Menteri Pendidikan Nasional Nomor 16 Tahun 2007 Tentang Standar Kualifikasi Akademik Dan Kompetensi Guru.

Penelitian ini dilaksanakan pada tahun 2019 di Kabupaten Bombana dengan subjek penelitian adalah guru, kepala sekolah dan perwakilan Dinas Pendidikan. Penelitian ini berfokus pada gambaran kompetensi guru, kendala yang dihadapi dan model/stategi pengembangan kompetensi. Pengumpulan data mengenai gambaran kompetensi guru menggunakan metode angket dan telaah data sekunder. Pengumpulana data mengenai kendala yang dihadapi guru dalam meningkatkan kompetensinya menggunakan metode angket dan wawancara. Begitu halnya dengan pengumpulan data mengenai model pengembangan kompetensi guru menggunakan metode angket dan wawancara. Peneliti merupakan instrumen utama sedangkan instrumen pendukung berupa lembar angket dan panduan wawancara. Kevalidan data ini diperoleh melalui trianggulasi metode dan trianggulasi sumber. Trianggulasi metode menggunakan metode angket yang dikomparasikan dengan metode wawancara dan telaah data sekunder. Begitu pula dengan trianggulasi sumber menggunakan sumber data dari guru, kepala sekolah dan dinas pendidikan. 
Analisis data secara deskriptif kuantitatif dilakukan terhadap hasil dari penilaian angket yang diberikan kepada guru, kepala sekolah dan dinas pendidikan sehingga memperoleh gambaran dalam bentuk kuantitatif terkait kompetensi guru. Hasil wawancara terkait kendala yang dihadapi guru dalam meningkatkan komptensinya dibuat dalam bentuk deskripsi hasil wawancara baik dari guru, kepala seklah maupun dinas pendidikan. Lain halnya dengan analisis data terkait model pengembangan kompetensi menggunakan analisis data faktor internal yang dikenal dengan IFAS, analisis data faktor eksternal yang dikenal dengan EFAS dan data SWOT (strengths, weaknesses, opportunities, and threats). Diagram analisis SWOT biasanya dimanfaatkan dalam kajian ekonomi namun dapat pula diaptasi untuk keperluan bidang pendidikan, dapat dilihat pada gambar sebagai berikut (Rangkuti, 2019).

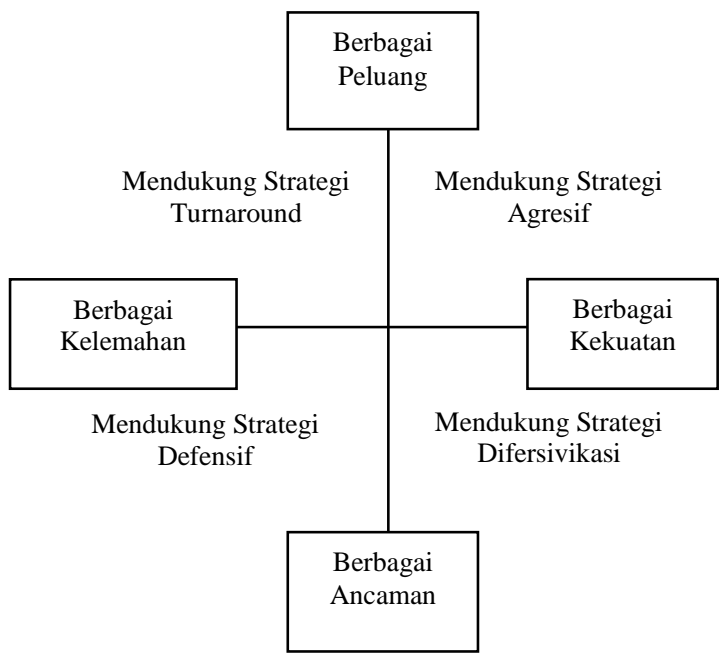

Gambar 1. Diagram analisis SWOT

Matrisk SWOT menunjukkan empat kemungkinan alternatif strategis berdasarkan hasil audit terhadap lingkungan internal dan lingkungan eksternal. Setelah data terkumpul, selanjutnya dianalisis menggunakan model grand strategy.

Kuadran 1: Ini merupakan situasi yang sangat menguntungkan. Lembaga pendidikan memiliki Peluang dan Kekuatan sehingga dapat memanfaatkan peluang yang ada. Strategi yang harus diterapkan dalam kondisi ini adalah mendukung kebijakan pertumbuhan yang agresif.
Kuadran 2: Meskipun menghadapi berbagai ancaman, lembaga pendidikan ini masih memiliki kekuatan dari segi internal. Strategi yang harus diterapkan adalah menggunakan kekuatan untuk memanfaatkan peluang jangka panjang dengan cara strategi diversifikasi.

Kuadran 3: Lembaga pendidikan menghadapi peluang pasar yang sangat besar, tetapi sisi lain, memiliki penghambat/kendala internal. Strategi yang harus diterapkan adalah meminimalisir fakotr penghambat sehingga dapat menarik peluang yang lebih baik

Kuadran 4: Yang tidak menguntungkan bagi lembaga pendidikan pada situasi ini, akibat permasalahan internal sehingga menjadi ancaman atau penghambat. Strategi yang harus diterapkan adalah defensif, contohnya memaksimalkan daya guna kerja.

Tahapan dalam analisis data, yaitu (1) data reduction yaitu mereduksi data berarti memilah bagian-bagian yang dianggap penting, menentukan pola dan temanya serta meninggalkan bagian-bagian yang tidak perlu, (2) data display, menampilkan data yaitu menyajikan data dengan teks yang bersifat naratif, grafik dan tabel, dan (3) conclusion drawing, yaitu data tentang kompetensi guru yang telah disajikan selanjutnya dianalisis untuk membuat suatu kesimpulan. Kevalidan data diperoleh melalui teknik triangulasi.

\section{HASIL DAN PEMBAHASAN}

\section{Deskripsi Kompetensi Guru}

Data diperoleh melalui angket yang diberikan kepada guru SD. Jawaban koresponden guru SD pada penilaian kompetensi adalah sebagai berikut:

Tabel 1. Jawaban koresponden

\begin{tabular}{lcccc}
\hline \multirow{2}{*}{ Kompetensi } & \multicolumn{4}{c}{ Persentasi (\%) } \\
\cline { 2 - 5 } & selalu & sering & jarang & kurang \\
\hline profesional & 25,02 & 67,14 & 7,84 & \\
pedagogik & 21,03 & 68,46 & 9,35 & 2,91 \\
sosial & 17,46 & 77,06 & 7,30 & \\
pribadi & 38,31 & 59,58 & 3,17 & \\
\hline
\end{tabular}


Berdasarkan tabel di atas memberikan gambaran bahwa kompetensi yang wajib dimiliki guru belum sepenuhnya diterapkan oleh guru. Masih terdapat guru yang menjawab jarang dalam menerapkan pada keempat kompetensi guru, bahkaan terdapat jawaban kurang pada kompetensi pedagogik. Jika dilihat daari indikator penilaian nampak bahwa masih terdapat guru yang jarang mempertimbangkan karakteristik peserta didik dalaam mendesain pembelajarannya, memotivasi belajar peserta didik dan melaksanakan manajemen kelas dengan baik. Begitu pula pada kompetensi pedagogik, guru kurang menerapkan metode interaktif dan melaksanakan pembelajaran sesuai perencanaan yang telah dibuat. Hasil temuan ini sejalan dengan temuan Nurochmah et al. (2017) yang menjelaskan bahwa hampir semua guru menyiapkan RPP namun tidak diterapkan karena bahannya hasil download dari sumber internet.

Jika merujuk pada hasil UKG tahun 2019 yang berfokus pada pengetahuan profesional dan pedagogik memang masih tergolong rendah yaitu 48,19. Guru lebih unggul dalam aspek kompetensi sosial dan pribadinya. Guru memiliki kompetensi professional dan kompetensi pedagogik yang rendah. Ini berbanding terbalik dengan aspek kompetensi sosial dan pribadinya yang tinggi.

Pada kompetensi sosial, guru jarang terlibat aktif pada kegiatan kemasyarakatan, dan membantu teman sejawat dalam kaitannya dengan permasalahan yang dihadapi dalam pembelajaran. Selain itu pada kompetensi pribadi, guru jarang memotivasi diri sendiri dan memotivasi teman sejawat untuk berkolaborasi memperbaiki kualitas dan mengembangkan keterampilan dalam mengajarnya.

\section{Kendala yang dihadapi guru}

Kendala guru yang biasa dihadapi berkaitan dengan kompetensi diketahui melalui hasil wawancara langsung pada responden pihak terkait baik dengan guru, kepala sekolah dan dinas pendidikan. Responden dari dinas pendidikan dan kebudayaan mengatakan bahwa secara umum kompetensi guru di kabupaten Bombana khususnya kompetensi pedagogik dan profesional masih rendah. Salah satu faktor rendahnya kompetensi tersebut karena faktor kelulusan alumni. Terdapat guru yang mengambil perkuliahan non regular (Sabtu-Minggu) sehingga kemampuan mengajarnya rendah. Akan beda antara lulusan reguler dan non regular. Dalam meningkatkan kompetensi maka perlu dilakukan penyaringan kualitas guru, dan penyaringan moralitas guru sehingga diperoleh guru yang berkualitas dan berkarakter (Susilowati et al., 2013).

Belum ada data konkrit tentang pengaruh signifikan terhadap peningkatan hasil belajar peserta didik antara guru tersertifikasi dan guru yang belum tersertifikasi. "Guru yang memiliki sertifikat pendidik seharusnya bisa lebih baik kualitas mengajarnya dibanding dengan yang belum sertifikasi. Namun disisi lain guru menyadaari kelemahannya dalam hal inovasi dan pembelajaran kontekstual (Anggranei, 2020). Kreatifitas dalam mengajarnya dapat ditingkatkan sehingga apa yang diharapkan dari tujuan sertifikasi guru yaitu meningkatkan kualitas dan mutu pendidikan dapat tercapai. Salah satu indikatornya adalah prestasi belajar peserta didik yang meningkat.

Tugas guru memang berat karena tuntutannya mencerdasarkan peserta didik, sehingga perlu memiliki kompetensi yang telah diamanatkan dalam peraturan. Guru terus berupaya beradaptasi dengan perubahan dan mampu berinovasi untuk ditranfer ke anak didiknya. Tidak kalah pentingnya adalah komitmen untuk menjalankan tugas sesuai dengan kewajibannya secara profesional. Kendalanya menurut pihak dinas pendidikan adalah sarana dan prasarana sebagai penunjang kompetensi guru belum tersedia secara maksimal dan keterbatasan dana yang ada untuk penganggaran peningkatan kompetensi seperti pelatihan, workshop, seminar dan lain-lain masih minim.

Hasil wawancara kepada kepala sekolah diperoleh informasi bahwa sejauh ini belum ditemukan kendala yang berarti dalam kompetensinya namun ada beberapa guru yang mengalami kendala dalam menerapkan K13. Dalam pembelajaran di kelas, guru menguasai materi pembelajaran dan dapat memanfaatkan berbagai model dan metode 
pembelajaran secara bervariasi namun masih terdapat guru yang belum dapat memanfaatkan ICT dalam pembelajarannya. Perlu adanya pembinaan dan pengawasan dari kepala sekolah terkait pembelajaran guru di kelas (Malikkhah \& Anam, 2020).

Dalam menangani peserta didik bermasalah, guru lebih menekankan pendekatan individu dan humanis untuk menyelesaikan masalah peserta didik. Beda halnya dengan kondisi sekolah di pedesaan. Guru masih dihadapkan masalah dasar yaitu motivasi belajar rendah dan minat peserta didik untuk bersekolah rendah. Sehingga guru lebih banyak bekerja untuk memotivasi belajar peserta didik dan mendorong mereka untuk tetap bersekolah.

Sejalan dengan pendapat responden dinas pendidikan dan kebudayaan, kepala sekolah juga memandang bahwa sarana dan prasarana sebagai penunjang kompetensi guru belum tersedia secara maksimal, media yang disediakan oleh sekolah masih terbatas dan masih terdapat guru yang sifatnya mengajar hanya memenuhi tugas saja tanpa adanya kemauan bagaimana cara meningkatkan kualitas mengajarnya. Adanya sarana dan prasarana yang lengkap dapat mendukung pembelajaran yang efektif (Nurochmah et al., 2017). Selain itu kurangnya pengetahuan guru dalam penerapan pendekatan, strategi, teknik dan metode yang bervariasi sesuai dengan karakteristik dan kebutuhan peserta didik. Guru di sekolah dasar harus mampu menjadi mediator dalam pembelajaran (Munawar, 2019). Kekurangannya lainnya adalah belum adanya penghargaan kepada guru berprestasi sehingga guru tidak termotivasi untuk meningkatkan kompetensinya. Tentunya akan mempengaruhi hasil pembelajaran yang diterima peserta didik.

Strategi yang ditawarkan oleh kepala sekolah untuk peningkatan kompetensi adalah melalui forum KKG dapat menjadi media informatif dan saling bertukar pikiran terkait permasalahan yang ditemui oleh guru dalam mengajarnya. Melalui KKG, guru saling bertukar informasi terkait pengalaman dan kendala yang dihadapi dalam pembelajaran (Idris et al., 2020). Selain itu perlu adanya pelatihan K13, workshop pengembangan media pembelajaran, keterampilan komputer, penulisan karya tulis ilmiah untuk peningkatan kompetensi guru.

Hasil wawancara dengan guru SD diketahui bahwa kendala guru hubunganya dengan kompetensi profesional seperti penguasaan materi atau penggunaan modelmodel pembelajaran dapat di atasi dengan mencari bahan atau materi terkait melalui akses internet. Untuk kendala ini Khairuna (2019) menyarankan perlu adanya pelatihan terkait pembelajaran kontekstual yang menekankan keaktifan dan keterlibatan peserta didik secara penuh dalam pembelajaran. Sejauh ini kendala yang berhubungan dengan kemampuan mengajar dapat di atasi, misalnya guru sering membuat media pembelajaran sendiri jika media tersebut tidak tersedia di sekolah. Informasi lainnya adalah guru telah menyiapkan RPP dalam melaksanakan pembelajaran. Dalam pelaksanaanya sudah mengikuti langkahlangkah yang direncanakan misalnya saat tahap awal pembelajaran, guru memotivasi dan berusaha menarik perhatian peserta didik agar fokus pada tujuan belajar.

Kendala lain adalah masih banyak guru yang belum mampu menerapkan K13 secara optimal dalam pembelajarannya. Selain itu kurangnya guru mata pelajaran tertentu seperti kesenian sehingga mata pelajaran tersebut diampu oleh guru mata pelajaran lain yang tidak sesuai bidang ilmu. Guru mengharapkan perlu adanya pelatihan K13, workshop pengembangan media pembelajaran, keterampilan komputer, penulisan karya tulis ilmiah untuk peningkatan kompetensi. Guru menginginkan adanya perhatian dari pihak-pihak terkait khususnya dinas pendidikan untuk meningkatkan penyediaan sarana dan prasarana yang dapat menghasilkan pembelajaran yang lebih baik. Pemerintah daerah juga perlu memberikan penghargaan kepada guru berprestasi untuk meningkatkan motivasi guru untuk berprestasi dan adanya dukungan wali peserta didik dalam upaya peningkatan prestasi peserta didik (Effendi \& Usman, 2021). 


\section{Model Strategi Pengembangan}

Strategi untuk pengembangan kompetensi guru SD disusun dengan menggunakan analisis SWOT yaitu mengkaji/menguji faktor-faktor yang mempengaruhi kinerja dan menyelesaikan problem suatu lembaga pendidikan. Diketahui melalui kekuatan dan kelemahan, peluang dan ancaman sehingga dapat dirumuskan solusi pemecahannya. Model analisis SWOT yang digunakan adalah analisis data faktor internal yang dikenal dengan IFAS, analisis data faktor eksternal yang dikenal dengan EFAS dan data SWOT (strengths, weaknesses, opportunities, and threats), dilanjutkan dengan memasukan kedalam model grand strategy.

Data dalam matriks IFAS yang telah dianalisis, memberikan gambaran bahwa upaya peningkatan kompetensi guru dapat ditempuh dengan beberapa cara, antara lain melalui pendidikan lanjutan dalam jabatan pelatihan dan seminar. Faktor ini dianggap menjadi faktor utama dengan diberi bobot 0,3 dan skor 5. Di sisi lain, para guru juga berpendapat dapat mengoptimalkan pengganggaran dan program BOS maupun sertifikasi guru sebagai upaya peningkatan kompetensi mereka.

Peluang lainnya yang dapat dimanfaatkan guru untuk pengembangan karier mereka adalah dengan terlibat langsung pada program-program pemerintah terkait pengembangan diri dan kompetensi. Selain itu, guru juga memiliki peluang untuk mengikuti ajang/event baik tingkat daerah, regional, nasional, maupun internasional. Peluang lainnya adalah tingginya kebutuhan masyarakat terhadap pelayanan pendidikan yang berkualitas.

Analisis matrik IFAS pada faktorfaktor yang dapat jadi kendala untuk guru yaitu belum maksimalnya perhatian pemerintah dirasakan oleh guru dalam upaya menfasilitasi pengembangan kompetensi mereka, memperoleh nilai mutu sebesar 0,25 dan skor sebesar 0,25. Selain itu, adanya kebijakan sistem pendidikan terutama kurikulum yang sering berubah memperoleh nialai mutu sebesar 0,15 dan skor sebesar 3 .
Kendala lainnya adalah yang dihadapi guru adalah masih banyaknya guru yang belum memanfaatkan kemajuan teknologi untuk meningkatkan kompetensinya dan relatif tingginya biaya untuk melanjutkan studi/pendidikan memperoleh nilai mutu sebesar 0,5 dan skor sebesar 3. Selain itu adanya rotasi mengajar dengan pelajaran berbeda dan belum adanya sanksi langsung bagi guru yang tidak menguasai materi dan konsep ilmu memperoleh nilai mutu sebesar 0,1 dan skor sebesar 3, sedangkan masih terdapat peserta didik yang tidak berminat untuk sekolah memperoleh nilai mutu sebesar 0,1 dan skor sebesar 2 .

Dari hasil analisis data matrik EFAS, dapat diketahui bahwa kekuatan guru adalah dapat memanfaatkan sumber belajar secara bervariasi dan meningkat. Faktor tersebut menjadi faktor utama dengan nilai mutu sebesar 0,2 dan memperoleh skor sebesar 4 . Selanjutnya, guru beranggapan bahwa mereka dapat menggunakan pendekatan, metode mengajar guru yang bervariasi, dan masing-masing kelas/bidang studi telah memiliki perangkat pembelajaran yang lengkap. Kekuatan lainnya adalah rata-rata kualifikasi akademik guru adalah S1 dan mata pelajaran yang diampu sesuai dengan bidang dan kualifikasi ijasahnya. Selain itu, hubungan baik antara kepala sekolah, guru dan peserta didik berjalan baik, sehingga proses pembelajaran dapat berjalan dengan lancar.

Data dalam matriks EFAS menujukkan kelemahan yang dialami lembaga pendidikan adalah kemampuan guru tidak merata, masih ada guru yang belum menguasai ICT atau literasi ICT dan masih rendahnya keterampilan guru menerapkan K13 memperoleh nilai mutu sebesar 0,1 dan skor sebesar 4. Apalagi di masa pandemi ini, penguasaan literasi ICT sangat dibutuhkan untuk pembelajaran daring (Anggranei, 2020). Kurangnya kemampuan dalam beradaptasi terhadap perubahan dan perkembangan dapat menjadi kelemahan dalam menyiapkan kebutuhan perseta didik di masa depannya.

Kelemahan lainnya adalah masih rendahnya guru yang memiliki publikasi 
karya ilmiah untuk pengembangan profesionalisme, belum semua guru dapat melaksanakan PTK (penelitian tindakan kelas) dan mempublikasikan karyanya baik dalam media massa maupun jurnal ilmiah. Di sisi lain, kepala sekolah dan guru belum memilikikomiten dalam mengaplikasikan/menerapkan hasil-hasil pelatihan atau workshop yang sudah diikuti. Begitu pula kelemahan pada penyusunan dan supervisi program sekolah belum optimal. Selain faktor guru, kelemahan lainnya juga berasal dari peserta didik yaitu rendahnya motivasi dan minat peserta didik untuk belajar dan berprestasi

Matrik SWOT berdasarkan hasil analisis tersebut digambarkan sebagai berikut:

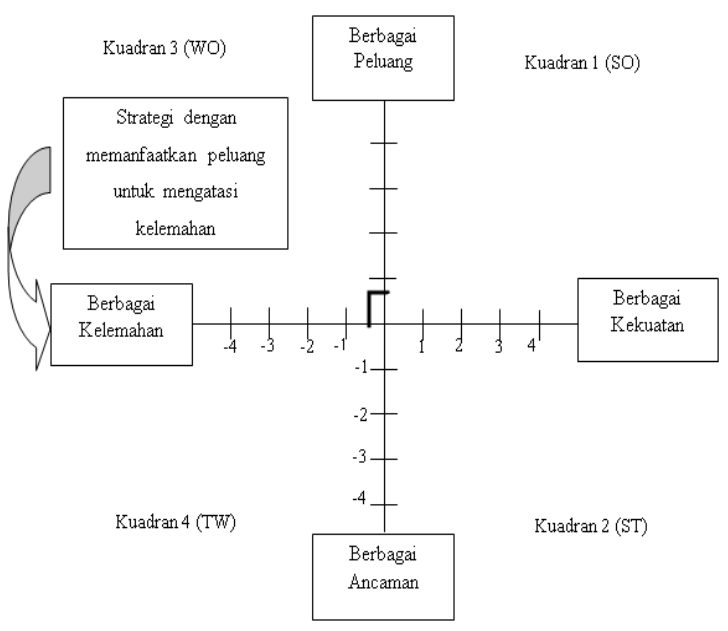

Gambar 2. Matrik SWOT

Hasil analisis matrik IFAS mengenai faktor-faktor yang menjadi kekuatan dan kelemahan diperoleh nilai mutu sebesar $-0,1$, sedangkan untuk matrik EFAS mengenai faktor-faktor peluang dan ancaman memperoleh nilai mutu sebesar 0,4. Ini berarti bahwa strategi yang dapat diterapkan terdapat pada posisi kuadran 3 atau WO (Weakness Opportunity) yaitu memanfaatkan peluang yang ada untuk mengatasi kelemahan yang dimiliki.

Berdasarkan gambar 2 tersebut dapat dilihat bahwa pada peningkatan kompetensi guru SD di kabupaten Bombana, strategi yang bisa digunakan adalah strategi turn arround, yaitu dengan memanfaatkan peluang yang ada untuk mengatasi kelemahan para guru. Kelemahan-kelemahan guru dieliminir sembari memanfaatkan peluang yang ada sehingga kompetensi guru dapat ditingkatkan.

Terselenggaranya pelatihan baik pelatihan pemantapan K13, optimalisasi KKG untuk guru SD, workshop penelitian tindakan kelas (PTK), pengembangan media pembelajaran, keterampilan komputer, dan penulisan karya tulis ilmiah jika direalisasikan secara optimal bisa untuk mengurangi kelemahan para guru. Tersedianya anggaran untuk guru guna melanjutkan studi dalam rangka pemerataan kualifikasi akademik pendidik yaitu minimal S1. Perlu adanya tim yang bentuk pada level sekolah yang bertugas untuk meningkatkan kompetensi pedagogik dan menjalin kerjasama dengan instansi terkait seperti LPTK atau lembaga pelatihan yang relevan dengan peningkatan kompetensi guru (Tyagita \& Iriani, 2018).

Terdapat empat langkah strategis untuk pengembangan kompetensi guru SD meliputi: pertama, melalui pendidikan dan pelatihan. Sekolah dapat mengirimkan gurunya untuk dilatih dengan output mendapatkan pengetahuan, keterampilan dan pembentukan sikap terbaik kaitan dengan tugasnya (Isnaini et al., 2020). Pelatihan seperti ini mengharuskan guru meninggalkan tugasnya di sekolah untuk sementara waktu, namun manfaatnya adalah guru lebih terkonsentrasi untuk mengikuti kegiatan sehingga tujuan yang ingin dicapai dapat lebih maksimal. Di sisi lain pelatihan ini tidak dapat dilaksanakan terlalu sering atau dengan durasi waktu yang relatif panjang. Ini dapat menjadi kontra produkftif terhadap keefektifan belajar di kelas karena lama ditinggalkan oleh gurunya, sedangkan guru dituntut untuk mampu memenuhi hak belajar peserta didik (Anggranei, 2020).

Kedua, pelatihan dalam bentuk In house trainnig (IHT). Berangkat dari pemikiran bahwa sebagian kemampuan dan keterampilan tidak harus ditempuh melalui pelatihan eksternal tetapi dapat memaksimalkan pelatihan secara internal melalui KKG (Rusdin, 2017). Guru-guru baru yang masih rendah kompetensinya dapat dilatih oleh guru yang memiliki kompetensi baik (guru senior) baik dari sekolah yang sama atau sekolah lainnya yang memiliki mutu yang 
lebih baik. Pelatihan ini dapat menjadi pengalaman guru dalam meningkatkan kompetensinya sesuai bidang ilmu masingmasing (Riyadin, 2016).

Ketiga, mengadopsi model peningkatan mutu pembelajaran di Jepang yaitu lesson studi. Kegiatan ini pada prinsipnya merupakan bentuk kolaborasi guru dan berkelanjutan dalam memperbaiki kinerja mengajarnya dan dampak positifnya terhadap proses dan kinerja belajar peserta didik dalam kelas (Supriyanto et al., 2020). Dalam kegiatan ini, guru secara berkelompok melakukan kolaborasi dalam pembelajaran di kelas mereka. Peserta didik diberi stimulus untuk dapat meningkatkan prestasi mereka, dan di sisi lain guru juga memacu diri untuk memperbaiki proses pembelajarannya. Melalui lesson study, guru dapat memenuhi kebutuhan belajar peserta didik melalui pembelajaran yang aktif, efektif dan inovatif (Junaid \& Baharuddin, 2020).

Keempat, melakukan perbaikan melalui kegiatan penelitian tindakan kelas (PTK). PTK dapat meningkatkan kualitas pembelajaran dan mampu memiliki karya pengembangan profesinya (Fitria et al., 2019). PTK dilaksanakan oleh guru dalam kelasnya masing-masing. PTK dapat dilakukan dengan berkolaborasi bersama rekan sejawat dalam pelaksanaanya, observasi aktivitas guru dan peserta, mengevaluasi dan melakukan refleksi pembelajaran. Tindakan yang dilakukan merupakan solusi terhadap kendala yang dihadapi. Karena itu maka dalam PTK perlu dilaksanakan dalam beberapa putaran/siklus hingga mencapai prestasi kinerja yang diharapkannya. Selain memperbaiki kualitas pembelajaran, itu PTK juga bermanfaat untuk membantu guru menyiapkan sertifikasi dan kenaikan pangkat mereka (Handayani \& Rukmana, 2020).

\section{SIMPULAN DAN SARAN}

Berdasarkan hasil penelitian dan pembahasan di atas dapat disimpulkan bahwa guru SD yang menjadi responden memiliki kompetensi professional dan kompetensi pedagogik yang rendah. Ini berbanding terbalik dengan aspek kompetensi sosial dan pribadinya yang tinggi. Dalam meningkatkan kompetensinya dipenggaruhi oleh beberapa faktor misalnya faktor kelulusan alumni, kendala dalam menerapkan K13, sarana dan prasarana yang mendukung pembelajaran guna menciptakan hasil pembelajaran yang baik. Strategi peningkatan kompetensi guru SD dapat dilakukan dengan menggunakan strategi turn arround, yaitu dengan memanfaatkan peluang yang ada untuk mengatasi kelemahan para guru untuk kompetensi sosial, profesional dan pedagogik. Strategi untuk kompetensi kepribadian dengan strategi agresif yaitu menggunakan kekuatan yang dimiliki oleh para guru agar dapat memanfaatkan peluang yang ada secara optimal.

Memperhatikan temuan penelitian ini, dinas terkait yaitu Dinas Pendidikan dan Kebudayaan Kabupaten Bombana perlu menyusun program tahunan untuk pengembangan kompetensi guru yang mengacu pada Permendiknas Nomor 16 Tahun 2007 Tentang Standar Kualifikasi Akademik dan Kompetensi Guru. Dalam pengembangan kompetensi sosial, profesional dan pedagogik, lembaga pendidikan dapat menggunakan strategi turn arround, yaitu dengan memanfaatkan potensi yang ada sehingga kelemahan dapat diatasi. Sedangkan untuk pengembangan kompetensi kepribadian dapat menggunakan strategi agresif yaitu menggunakan kekuatan yang dimiliki untuk dapat memanfaatkan peluang yang ada secara optimal.

\section{DAFTAR PUSTAKA}

Anggranei, F. N. (2020). Realitas Kompetensi Guru Pasca Sertifikasi. Scientific Journal Of Reflection: Economic, Accounting, Management and Business, 3(4), 331340. https://doi.org/10.37481/sjr.v3i4.229

Baharudin, H. (2017). Peningkatan Kompetensi Guru Melalui Sistem kepemimpinan Kepala Madrasah. Jurnal Ilmu Tarbiyah At-Tajdid, 6(1), 1-26. http://ejournal.inismupacitan.ac.id/index. php/tajdid/article/view/38

Effendi, Y., \& Usman, N. (2021). Strategi Peningkatan Profesionalisme Guru Dalam Rangka Meningkatkan Kualitas Pendidikan di Indonesia. 
https://www.snastep.com/proceeding/ind ex.php/snastep/article/view/5

Fitria, H., Kristiawan, M., \& Rahmat, N. (2019). Upaya Meningkatkan Kompetensi Guru Melalui Pelatihan Penelitian Tindakan Kelas. Abdimas Unwahas, 4(1), 14-25. https://doi.org/10.31942/abd.v4i1.2690

Fredy, Tembang, Y., \& Purwanty, R. (2019). Analisis Kepuasan Orangtua dan Siswa terhadap Kualitas Layanan Pendidikan Dasar. Musamus Journal of Primary Education, 2(1), 59-66. https://doi.org/10.35724/musjpe.v2i1.187 4

Handayani, S. L., \& Rukmana, D. (2020). Peningkatan Kemampuan Menulis Karya Ilmiah Guru Melalui Pelatihan Penelitian Tindakan Kelas bagi Guru SD. Publikasi Pendidikan, $\quad 10(1), \quad 8$. https://doi.org/10.26858/publikan.v10i1.9 752

Idris, A. N., Yunus, M., \& Asdar. (2020). Strategi Pengembangan Kompetensi Guru Sekolah Dasar Negeri 22 Kabupaten Maros. Bosowa Journal of Education (BJE), 1(20), 9-15. https://doi.org/10.35965/bje.v1i1.465

Isnaini, F. Z., Siwiyanti, L., \& Hurri, H. I. (2020). Analisis Pendidikan dan Pelatihan dalam Peningkatan Kompetensi Profesional Pendidik Paud di Kota Sukabumi. Jurnal Utile, 4(2), 200-209. https://doi.org/10.37150/jut.v6i2.878

Jatirahayu, W. (2013). Guru Berkualitas Kunci Mutu Pendidikan. Jurnal Ilmiah Guru "Cope," 2(2). https://journal.uny.ac.id/index.php/cope/a rticle/view/3005

Junaid, R., \& Baharuddin, M. R. (2020). Peningkatan Kompetensi Pedagogik Guru melalui PKM Lesson Study. To Maega: Jurnal Pengabdian Masyarakat, $3(2)$, 122-129. https://doi.org/10.35914/tomaega.v3i2.41 3

Kartowagiran, B. (2011). Kinerja Guru Profesional (Guru Pasca Sertifikasi).
Cakrawala Pendidikan, 23(3), 202-210. https://doi.org/10.21831/cp.v3i3.4208

Khairuna, K. (2019). Meningkatkan Kompetensi Profesional Guru dalam Menerapkan Strategi Pembelajaran Kontekstual Melalui Workshop dan Supervisi Akademik di SMP Alwasliyah 1 Medan pada Tahun Pelajaran 2018/2019. Jurnal Biolokus, 2(1), 5. http://dx.doi.org/10.30821/biolokus.v2i1. 445

Malikkhah, Z., \& Anam, N. (2020). Strategi Kepala Sekolah Dalam Meningkatkan Kompetensi Guru Di Madrasah Ibtidaiyah (Mi). Jurnal Mu'allim, 2(2), 242-259.

https://doi.org/10.35891/muallim.v2i2.22 63

Munawar, M. (2019). The application of STAD-Cooperative Learning Model: Efforts to increase motivation and Learning Outcomes of students in Class 5 SD N 07 Ledok Salatiga in Mathematics subjecth in Folding Symmetry and Rotating Symmetry topics. MUDARRISA: Jurnal Kajian Pendidikan Islam, 11(2), 114-135. https://doi.org/10.18326/mdr.v11i2.114135

Musfah, J. (2012). Peningkatan Kompetensi Guru: Melalui Pelatihan dan Sumber Belajar Teori dan Praktik. Jakarta: Kencana. Google Scholar

Naria, K. L. D. S. N. D. arta, Nurhidayah, \& Gabriella, F. (2020). Analisis Kompetensi Pedagogik Guru dalam Pelaksanaan Kurikulum 2013. Seminar Nasional Ilmu Pendidikan Dan Multi Disiplin 3 (SNIPMD 3), 3, 312-322. https://prosiding.esaunggul.ac.id/index.p $\mathrm{hp} / \mathrm{snip} /$ article/view/25

Ngurah, D., \& Laksana, L. (2018). Pendidikan Berkualitas Dan Berkelanjutan Di Era Pembelajaran Abad 21. 5(1), 2. https://jurnalilmiahcitrabakti.ac.id/jil/inde x.php/jil/article/view/27/28

Nurhaidah, \& Musa, M. I. (2015). Pelayanan Pendidikan Yang Berkualitas Di Era Global Dalam Mengembangkan Potensi 
Peserta Didik Secara Maksimal. Jurnal Pesona Dasar, 1(4), 52-65. http://jurnal.unsyiah.ac.id/PEAR/article/v iew/7525

Nurochmah, A., Bachtiar, M., \& Basri, S. (2017). Peranan Kemampuan Manajerial Kepala Sekolah Dalam Rangka Meningkatkan Mutu Pendidikan Di Tingkat Sekolah Dasar Kecamatan Mandai Kabupaten Maros. Publikasi Pendidikan, $7(1), \quad 6$. https://doi.org/10.26858/publikan.v7i1.28 32

Peraturan Menteri Pendidikan Nasional No. 16 Th. 2007 tentang Standar Kualifikasi Akademik dan Kompetensi Guru. http://vervalsp.data.kemdikbud.go.id

Rangkuti, F. (2019). SWOT Balanced Scorecard: Teknik Menyusun Strategi Korporat yang Efektif Plus Cara Mengelola Kinerja dan Resiko. Jakarta: PT Gramedia. Google Scholar

Riyadin, S. (2016). Kebijakan Pengembangan Profesionalisme Guru PNS. JKMP, 4(2), 219-234. https://doi.org/10.21070/jkmp.v4i2.697

Rusdin, R. (2017). Pendidikan dan Pelatihan Sebagai Sarana Peningkatan Kompetensi Guru di SMP Negeri 02 Linggang Bigung. Jurnal Administrative Reform, 5(4), 200. https://doi.org/10.52239/jar.v5i4.885

Sabaniah, S., Ramdhan, D. F., \& Rohmah, S. K. (2021). Peran Guru dalam Pelaksanaan Pembelajaran Jarak Jauh di Tengah Wabah Covid - 19. Edunesia: Jurnal Ilmiah Pendidikan, 2(1), 43-54. https://doi.org/10.51276/edu.v2i1.77

Sofiarini, A., \& Elya Rosalina. (2021). Analisis Kebijakan dan Kepimpinan Guru Dalam Menghadapi Kurikulum 2013 Era Globalisasi. Jurnal Basicedu,
5(5),

4120-4126. https://doi.org/10.31004/basicedu.v5i5.13 47

Suhandani, D., \& Julia. (2014). Identifikasi Kompetensi Guru Sebagai Cerminan Profesionalisme Tenaga Pendidik Di Kabupaten Sumedang (Kajian Pada Kompetensi Pedagogik). Mimbar Sekolah Dasar, 1(2), 128-141. https://doi.org/10.17509/mimbarsd.v1i2.874

Supriyanto, A., DS, W., \& Herdianto, R. (2020). Peningkatan Kompetensi Mengembangkan RPP melalui Lesson Study bagi Guru SD Laboratorium. Jurnal Pendidikan: Teori, Penelitian, Dan Pengembangan, 5(2), 243. https://doi.org/10.17977/jptpp.v5i2.1318 7

Susilowati, I., Sutanto, H. A., \& Daharti, R. (2013). Strategi Peningkatan Kompetensi Guru Dengan Pendekatan Analysis Hierarchy Process. JEJAK: Jurnal Ekonomi Dan Kebijakan, 6(1), 80-92. https://doi.org/10.15294/jejak.v6i1.3750

Tyagita, B. P. A., \& Iriani, A. (2018). Strategi Peningkatan Kompetensi Pedagogik Guru Untuk Meningkatkan Mutu Sekolah. Kelola: Jurnal Manajemen Pendidikan, 5(2), 165-176. https://doi.org/10.24246/j.jk.2018.v5.i2.p 165-176

Undang-undang No. 14 Th. 2005 Tentang Guru dan Dosen. https://peraturan.bpk.go.id

Undang-undang No. 20 Th. 2003 tentang Sistem Pendidikan Nasional. https://peraturan.bpk.go.id 